\title{
Characterization of the Influenza Virus Inhibiting Fractions of Bergenia ligulata
}

\author{
M. Rajbhandari ${ }^{1}$ and Th. Schoepke ${ }^{2}$ \\ ${ }^{1}$ Research Center for Applied Science and Technology, Tribhuvan University, Kathmandu \\ 2Institute of Pharmacy, Department of Pharmaceutical Biology, University of Greifswald, D-17487, Germany \\ e-mail:pkkme@wlink.com.np
}

\begin{abstract}
In the course of screening of plant extracts for anti-influenza viral activity, $50 \%$ aqueous methanolic extract exhibited antiviral activity against influenza virus A. Bio-assay guided fractionation of the extract led to the indication of the presence of condensed tannins as the active constituents. This was confirmed by chemical tests as well as by thin layer chromatographic comparison with known tannin containing plant extracts. The active fractions were also analysed for the presence of carbohydrates by gas chromatography.
\end{abstract}

Kew words: Bergenia ligulata, anti-influenza, carbohydrates, condensed tannins.

\section{Introduction}

The development of effective antiviral agents has been the subject of global interest in public health. Although many synthetic anti-viral drugs are available, still better drugs are required due to the toxicity and narrow spectrum of activity of the existing drugs and emergence of drug resistant viruses. Thus, the search for safe and effective drugs is one of the important challenges in this decade. Ethnopharmacological approach is one of the fruitful approach for the search for new anti-viral agents of plant origin. Nepal has an enormous wealth of information on ethnopharmacology based remedies which are not only cheap and abundant but also culturally accepted. Therefore, plants with medicinal values should be investigated to determine their potential as a source of new drugs. Nepalese medicinal plants could be the starting logical point for the drug development program which can provide safe, stable and effective products for use in primary health care or can lead to the discovery of new biologically active component that may be use as a drug. Therefore, the present investigation was carried out to characterize the active fractions of B. ligulata of Nepalese origin. Bergenia ligulata (Wall.) Engl., (syn: Saxifraga ligulata Wall.,) (Saxifragaceae) commonly known as rock foil and locally as Pashanved is distributed throughout Nepal at an altitude between $1600-3200 \mathrm{~m}$ on shady and moist rocky slope (Malla et al. 1986). It is a perennial rhizomatous herbs having stout, woody and brownish rootstock. In Nepalese traditional medicine the roots are widely used against various diseases such as cough, cold, bronchitis, lung disease and fever.

The plants belonging to genus Bergenia contain elevated amount of tannin (Lin 1977). Preliminary investigation of $B$. ligulata has revealed the presence of tannins, carbohydrates and glycosides as polar constituents (Singh et al. 2009).

In our previous study $50 \%$ aqueous methanol extract of B. ligulata showed potent anti-influenza viral activity with an $\mathrm{IC}_{50}$ value of $10 \mu \mathrm{g} / \mathrm{ml}$ without any toxicity with a selectivity index of 10 (Rajbhandari et al. 2001). In addition the extract also inhibited the viral RNA synthesis and reduced peptide synthesis at 10 
$\mu \mathrm{g} / \mathrm{ml}$. We have reported that the virus inhibitory effect could be related to the presence of condensed tannins in the extract (Rajbhandari et al. 2003). In this paper, we report the detailed phytochemical and gas chromatographic investigations to characterize the active fractions.

\section{Methodology \\ Plant materials}

The rhizomes of Bergenia ligulata were collected from Kavre district and authenticated by comparison with herbarium specimens at the Central Department of Botany, Tribhuvan University. A voucher specimen (\#1568) is deposited at Research Centre for Applied Science and Technology, RECAST, Tribhuvan University.

\section{Extraction}

Dried rhizomes of $B$. ligulata (500 g) were finely pulverised and successively extracted with dichloromethane and methanol in a Soxhlet extraction apparatus followed by reflux with $50 \%$ aqueous methanol. The solvent was evaporated under reduced pressure and finally dried by lyophilisation to get the respective extracts (4.9, 82.2 and $16.6 \mathrm{~g})$.

\section{Activity guided fractionation}

The $50 \%$ aqueous methanolic extract of $B$. ligulata (10 g) was subjected to the Diaion HP-20 (Medium granular blue, 6-10 mesh, Ishizu Pharma) column and eluted with $2 \mathrm{l}$ water, 21 50\% aqueous methanol and $2 \mathrm{l}$ methanol. Three major fractions, D-1 (water fraction, $3.45 \mathrm{~g}$ ), D-2 (50\% methanol fraction, $4.5 \mathrm{~g}$ ) and D-3 (methanol fraction, $1.87 \mathrm{~g}$ ) were collected. The antiviral activities $\left(\mathrm{IC}_{50}\right)$ of the different fractions were $>100$ $\mu \mathrm{g} / \mathrm{mL}$ for $\mathrm{D}-1,<12.5 \mu \mathrm{g} / \mathrm{ml}$ for $\mathrm{D}-2$ and $12.5 \mu \mathrm{g} / \mathrm{mL}$ for $\mathrm{D}-3$. The most active fraction D-2 was subjected to a Sephadex LH 20 column equilibrated with $50 \%$ of aqueous methanol and eluted with the same solvent system. The sub-fractions were collected and monitored by TLC on cellulose F plate using a mixture of solvent systems, butanol-ethanol-water (20:5:11) and butanol-ethanol-methanol-water (20:5:0.5:11). The spots were visualized by spraying the plates with anisaldehyde- $\mathrm{H}_{2} \mathrm{SO}_{4}$, vanillin- $\mathrm{HCl}$ and $p$ dimethylaminocinnamaldehyde- $\mathrm{HCl}$ reagents. The sub-fractions were pooled into two major fractions, D2-1 (420 mg) and D-2-2 (290 mg). The column was then eluted with pure methanol. The methanol eluate was monitored by TLC and pooled together to get another fraction, D-2-3 (810 mg). The antiviral activities ( IC $_{50}$ ) of the different fractions were $>50 \mu \mathrm{g} / \mathrm{mL}$ for $\mathrm{D}-2-1$ and $<12.5 \mu \mathrm{g} / \mathrm{mL}$ for $\mathrm{D}-2-2$ and $\mathrm{D}-2-3$.

\begin{abstract}
Antiviral test
Confluent monolayers of MDCK cells were preincubated with serial dilutions of the plant extracts/ fractions $(100,50,25$ and $12.5 \mu \mathrm{g} / \mathrm{mL})$ in triplicate for $30 \mathrm{~min}$ at $37^{æ \%} \mathrm{C}$. A suspension of influenza virus A containing 30 TCID $_{50}$ was added and further incubated for $72 \mathrm{~h}$ at $37^{æ \%} \mathrm{C}$. Antiviral activity was determined by the MTT columetric test as described before (Rajbhandari et al 2003).
\end{abstract}

\section{Chemical analysis of the extract/fractions}

Polysaccharides were analysed by the Anthrone and Molisch test using D (+) galactose as a standard compound. Polyphenols were analysed by ferric chloride test using catechin and tannic acid as the standard compounds. Procyanidins were analysed by the ferric ammonium sulphate-hydrochloric acid test (Porter et al, 1986), vanillin-hydrochloric acid test (Broadhurst et al. 1978) and pdimethylaminocinnamaldehyde-hydrochloric acid test (Delcour et al. 1985) using catechin as a standard compound. Presence of ellagitannins was analysed by use of the sodium nitrite-acetic acid reagent (BateSmith, 1972). Standard test substance, extract and fractions were solved at a concentration of $5 \mathrm{mg} / \mathrm{mL}$ in $50 \%$ aqueous methanol or water.

\section{Carbohydrate analysis}

For the qualitative and quantitative determination of neutral monosaccharides by Gas Chromatography, the method of Blakeney et al. was adopted (Blakeney et al. 1983). Each $5 \mathrm{mg}$ of the active fraction was mixed with $1 \mathrm{mg}$ myo-inositol as an internal standard and hydrolysed with $1 \mathrm{~mL}$ of $2 \mathrm{M}$ trifluroacetic acid for $1 \mathrm{~h}$ at $121^{\circ} \mathrm{C}$ and 2 bar in a sealed test tube. The resulting product of the hydrolysis was mixed with $5 \mathrm{~mL}$ of water, neutralised with $200 \mu \mathrm{L} 1 \mathrm{M}$ ammonia and reduced with $1 \mathrm{~mL} 2 \%$ sodium borohydride solution in DMSO at $40{ }^{\circ} \mathrm{C}$ for $2 \mathrm{~h}$. The excess of ammonia was neutralised by the addition of $100 \mu \mathrm{l}$ acetic acid and the resulting alditole was mixed with $2 \mathrm{~mL}$ distilled acetic anhydride and acetylated at room temperature for $10 \mathrm{~min}$ in the presence of $200 \mu \mathrm{L}$ methylimidazole as a catalyser. The acetylated product was diluted with $10 \mathrm{~mL}$ distilled water and treated with $1 \mathrm{~mL} 0.1 \mathrm{M}$ sulphuric acid and 
extracted with dichloromethane in separatory funnel. The solvent was concentrated under the stream of nitrogen and $1 \mu \mathrm{l}$ of this concentrated solution was used for the gas chromatographic analysis (HP 5890 series II, Fa. Hewlett Packard, USA). Nitrogen was used as the carrier gas. A fused silica wall coated open tubular (WCOT) capillary column (25m x 0.25 mm ID) was used. The stationary liquid phase of the column was polysiloxane of the type OV-225-0.25. The column temperature was maintained isothermally at $230^{\circ} \mathrm{C}$ and the injector and detector temperature was maintained at $240{ }^{\circ} \mathrm{C}$. The sample was injected into the heated injection port. The injection split ratio was $1 / 100$. The flow rate was $1 \mathrm{ml} / \mathrm{min}$. Chromatogram was detected using a flame ionisation detector (FID).

The alditols were identified by comparison of their retention time with the authentic standard samples prepared at a concentration of $1 \mathrm{mg} / \mathrm{ml}$. The area occupied by each peak in the presence of internal standard was calculated with the help of the integration program HP 3365 Ser. II Chemstation and the percentage of each monosaccharide was determined.

\section{Selection of tannin containing plants and preparation of standard phenolic extracts}

The following tannin containing plants, Aesculus hippocastanum 1. (leaf), Quercus robur (fruit), Crataegus monogyna Jacq. emend. Lindm. (leaf), Pinus sylvestris l. (needle) and Vaccinicum myrtillus l. (leaf) were selected on the basis of the literature data [11] for the chemical tests and comparison of TLC characters with $B$. ligulata fractions. Each $2 \mathrm{~g}$ dried or $5 \mathrm{~g}$ fresh plant materials were percolated overnight with methanol, solvent was evaporated and mixed with $50 \mathrm{~mL}$ water and extracted with $50 \mathrm{~mL}$ petrol ether (bp $60-85^{\circ} \mathrm{C}$ ) three times. The aqueous solution was then extracted with $100 \mathrm{~mL}$ ethylacetate two times, the solvent was evaporated to get the crude phenolic extracts which were directly used for the TLC analysis on cellulose F plate.

\section{Results}

The methanol-water extract of B. ligulata showed potent activity against the replication of influenza $\mathrm{A}$ virus with an $\mathrm{IC}_{50}$ value of $10 \mu \mathrm{g} / \mathrm{ml}$ without any toxicity to MDCK cells. Additionally the activity of the extract was proven by several specific experiments. The extract inhibited viral RNA synthesis and reduced viral peptide synthesis at $10 \mu \mathrm{g} / \mathrm{mL}$. Pretreatment of cells with the extract was found to be effective to prevent cell destruction (Rajbhandari et al. 2005). For this reason, the extract was further worked up for the characterization of the active fractions.

A preliminary phytochemical screening of the extract indicated the presence of polyphenols and carbohydrates by the conventional ferric chloride and anthrone tests which gave dark blue and green colour respectively.

The extract was fractionated by Diaion HP 20 column chromatography and three fractions were collected. The fractions D-2 and D-3 inhibited the replication of influenza A virus on MDCK cells.

The fraction D-2 was further fractionated by Sephadex® LH 20 column chromatography and again three fractions were collected. The fractions D-2-2 and D-2-3 showed potent activity against the replication of influenza A virus.

Fraction D-2 and D-3 obtained from Diaion HP 20 column and D-2-2 and D-2-3 obtained from Sephadex LH 20 column were analysed for the presence of carbohydrates by gas chromatographic method. The total percentage of neutral sugar present in each fraction and the amount of individual sugars were determined. The results are shown in Table 1.

Table 1. $\mathrm{IC}_{50}$ values and Gas chromatographic determination of neutral sugar and individual sugars

\begin{tabular}{l|l|l|l|l|l|l|l|l|}
\hline \multirow{2}{*}{ Fractions } & IC & \multirow{2}{*}{$\begin{array}{l}\text { Neutral } \\
\text { sugar }\end{array}$} & \multicolumn{5}{|c|}{ Individual sugars } \\
\cline { 4 - 9 } & values & suamnose & Arabinose & Xylose & Mannose & Galactose & Glucose \\
\hline $\mathrm{D}-2$ & $<12.5$ & $6.1 \%$ & 3.8 & 49.2 & - & 5.6 & 10.8 & 30.6 \\
$\mathrm{D}-3$ & 12.5 & $7.7 \%$ & 1.9 & 46.1 & 1.8 & 6.3 & 9.7 & 34.2 \\
$\mathrm{D}-2-2$ & $<12.5$ & $1.8 \%$ & - & 29.8 & - & - & 13.8 & 56.4 \\
$\mathrm{D}-2-3$ & $<12.5$ & $1.1 \%$ & - & 29.5 & 16.3 & - & 17.3 & 36.9 \\
\hline
\end{tabular}


The 50\% aqueous methanolic and methanolic fraction obtained from Diaion HP 20 column (D-2 and D-3) contain 6.1 and $7.7 \%$ neutral sugar respectively. The other two fractions, D-2-2 and D-2-3 obtained from Sephadex LH 20 column contain relatively low amount of neutral sugar, only 1.8 and $1.1 \%$ respectively. The results showed that purification of the active fractions by Sephadex LH 20 column chromatography reduced the content of carbohydrate to a minimum with the retention of antiviral activity. This indicated that the fractions D-2-2 and D-2-3 are richer in polyphenols.

Hence, it can be assumed that phenolic compounds, especially condensed tannins are responsible for antiviral activity. Its presence was confirmed by specific colour reactions such as vanillin-hydrochloric acid test and $p$-dimethylaminocinnamaldehydehydrochloric acid test which gave pink red and blue colour respectively, characteristic of condensed tannins. The negative test with sodium nitrite-acetic acid indicated the absence of ellagitannins.

Irrespective of the total amount of neutral sugar present in each sample, all the four samples contain high amount of arabinose, glucose and galactose. Very low amounts of rhamnose and mannose are present in both fractions obtained by Diaion HP 20 column chromatography and they are totally absent in both fractions obtained from the Sephadex LH 20 column. In the methanolic fraction (D-3) of the Diaion HP 20 column chromatography very low amount of xylose is present. The fraction D-2-3 obtained from Sephadex LH 20 column chromatography contains reasonable amount of xylose.

The active fractions were further investigated by thin layer chromatographic comparison with condensed tannin containing plants (Thomoson et al. 1972). The tannin containing plants were collected and the ethylacetate extracts were prepared for the comparison of TLC on cellulose F plate. TLC separations were carried out in the solvent system butanol-ethanolwater, 20:5:11 (v/v/v) and butanol-ethanol-methanolwater, 20:5:0.5:11(v/v/v/v). The spots were localised on the chromatogram by using anisaldehyde- $\mathrm{H}_{2} \mathrm{SO}_{4}$ vanillin- $\mathrm{HCl}$ and $p$ dimethylaminocinnamaldehyde- $\mathrm{HCl}$ reagents which produced rose red, pink red and greenish blue spots respectively on the white background. Comparison of TLC with procyanidine containing plants indicated that the active fractions of $B$. ligulata contain some additional bands $\left(\mathrm{R}_{\mathrm{f}} 0.15,0.24\right.$ and 0.33$)$ which are more polar than the known procyanidines reported in reference plants. Thus, these bands could be the polymers of unknown catechin/epicatechin type of compounds.

\section{Discussion}

The results of our study indicated that the virus inhibitory effect of the active fractions is related to the presence of polyphenols, especially condensed tannins due to the low content of carbohydrates.

It was reported that plant phenols and protein bound polysaccharides have anti-influenza activity (Nagi et al. 1992). On the basis of these results the strong antiviral activity of the B. ligulata extract could be also caused by the presence of polysaccharides and/ or polyphenols. It is well known that antiviral activities of polysaccharides are linked to the anionic features of the molecules and that they inhibit the very early stages of viral infection such as attachment and penetration (Shannon et al. 1984). On the other hand, polyphenols, specially condensed tannins inhibit the growth of influenza A and B by inactivating hemagglutination which is essential for the virus adsorption (Nakayama et al. 1993).

Recently, many polyphenols rich plant extracts have been reported for their anti-influenza viral activity. For example, high molecular weight polyphenols in the fruits of Chaenomeles sinensis neutralizes influenza virus by inhibiting hemagglutination activity and by suppressing NS2 protein synthesis (Sawai et al 2008). Similarly, anti-influenza activity of pomegranate polyphenols is modulated by small changes in envelope glycoproteins (Sundararajan et al. 2010). On the other hand, virus inhibitory effect of polyphenol rich extract of Cistus incanus to be mainly due to binding of the polymeric polyphenol components of the extract to the virus surface, thereby inhibiting binding of the hemagglutinin to cellular receptors (Ehrhardt et al. 2007). In our previous study of pre-treatment of MDCK cells with $B$. ligulata extract before virus infection confirmed that the extract has effect on the early stage of viral infection by preventing the binding of virus particle to the cells (Rajbhandari et al. 2003). In this respect, the mechanism of virus inhibiting effect of our extract is quite similar to the other polyphenol rich plant extracts. Thus, a local application of $B$. ligulata 
M. Rajbhandari \& Th. Schoepke/Characterization of the.......

extract at the viral entry routes may be a promising approach that may help to protect from influenza virus infections. This study indicated that the medicinal plants used in Nepalese traditional therapy could be the alternative source for the development of new therapeutic agents to combat with the flu.

\section{Acknowledgements}

Prof. Dr. W. Blaschek, Institute for Pharmaceutical Biology, University of Kiel is gratefully acknowledged for his kind co-operation for carbohydrate analysis.

\section{References}

Bate-Smith, E. C. (1972) Phytochemistry 11, 1153-1158

Blakeney, A. B. Harris, P. J., Henry, R. J., Stone, B. A. (1983) Carbohydrate Research. 113, 291-299.

Broadhurst, R. B., Jones, W. T. (1978) Journal of the Science Food and Agriculture 29, 788-794.

Delcour, J. A. de Varebeke, D. J. (1985) Journal of the Institute of Brewing 1985, 91, 37-40.

Ehrhardt C., Hrincius E. R., Korte V., Mazur I., Droebner K., Poetter A. Dreschers S., Schmolke M., Planz O., Ludwig S. (2007) Antiviral Research 76 (1), 38-47

Lin Qishou (Ed.) Constituents and Chemistry of Chinese Medicinal Herbs (1977) p 254. The Science Publishing House, Peking.
Malla, S. B., Rajbhandari, S. B., Shrestha, T. B., Adhakari, P. M. Adhakari, S. R. and Shakya P. R. (Eds.) Flora of Kathmandu valley. Bull. Dept. Med. Plants No. 11 (1986) HMG Ministry of Forestry and soil conservation, Departmental of Medicinal plants, Thapathali, Kathmandu.

Nagi, T. Miyaichi, Y. Tomimori, T, Suzuki, Y., Yamada, H. (1992) Antiviral Research 19, 207-217.

Nakayama, M. Suzuki, K. Toda, M., Okubo, S., Hara, Y., Shimamura, T. (1993) Antiviral Research 21, 289-299.

Porter, L. J. Wong, R. Y., Benson, M., Chan, B. G. (1986) Journal of Chemical Research (S) 86-87.

Rajbhandari, M., U. Wegner, M. Juelich, Th. Schoepke, R. Mentel, (2001) Journal of Ethnopharmacology 74, 251-255.

Rajbhandari, M., U. Wegner, Th. Schoepke, U. Lindequist, R. Mentel, (2003) Die Pharmazie 58 : 268-271.

Sawai, R., K. Duroda, T. Shibata, R. Gomyou, K. Osawa, K. Shimizu, (2008) Journal of Ethnopharmacology 118 (1), 108-12.

Shannon, W. M., Mechanism of action and pharmacology: chemical agents. (1984). In: Galasso, G. J., Merigan, T. C., Buchanon, R. A. (Eds.) Antiviral Agents and Viral Diseases of Man. Raven Press, New York p 55-121.

Singh, N., Juyal, V. Gupta, A. K. Gahlot, M., Hariratna (2009) Journal of Pharmacy research 2, 1444-1447.

Sundararajan, A. Ganapathy, R. Huan, L., Dunla, J. R., Webby, R. J. Kotwal, G. J. Sangster , M. Y. (2010). Antiviral Research 88 (1), 1-9

Thompson, R. S. Jacques, D. Haslam, E. Tanner, R. J. N. (1972) Journal of Chemical Society Perkin I, 1387. 
Nepal Journal of Science and Technology 12 (2011) 290-295 